\title{
The Influences of Cyber Extension and Communication Media (Facebook, WhatsApp, Youtube) on Innovation Adoption in Nganjuk Regency
}

\author{
Rini Purwiyati ${ }^{{ }^{*},}$, Ahsin Daroini ${ }^{2}$, Abu Talkah ${ }^{3}$ \\ Department of Magister Agribusiness, Postgraduate, Islam Kadiri University, Jl. Sersan Suharmaji No.38, \\ Manisrenggo, Kediri, East Java, Indonesia
}

Received: 3 December 2019; Revised: 30 January 2020; Accepted: 22 April 2020

\begin{abstract}
Agricultural information is one of the important factors in agricultural production. Communication Information Technology (ICT) in the agricultural sector will lead to sustainable agriculture through the preparation of agricultural information that is timely, relevant in the decision-making process to increase its productivity. This study aimed to determine the effect of the Cyber extension and communication media on the innovation adoption in Nganjuk Regency. The study was conducted in Nganjuk Regency from June to September 2019, with a sample size of 110 people. The study was designed using SEM approach with the help of AMOS 21 application. The results showed the openness of farmers in Nganjuk Regency to the Cyber extension extension media had the highest score on the Cyber Extension extension media variable, this was due to ownership of communication equipment, selection of communication equipment types, availability of communication networks and high desire to find suitable information. WhatsApp communication media indicator had the highest score on the communication media variable, this was due to the communication media according to the needs of farmers in Nganjuk District, easy to use and able to reach broad communication. Cyber extension extension media and communication media influence the adoption of innovation, because appropriate extension media and communication media can accelerate the process of innovation adoption.
\end{abstract}

Keywords: cyber; extension; communication; media; innovation

\section{How to Cite:}

Purwiyati, R., Daroini, A., \& Talkah, A. (2020). The Influences of Cyber Extension and Communication Media ( Facebook, WhatsApp , Youtube ) on Innovation Adoption in Nganjuk Regency. HABITAT, 31(2), 86-94. https://doi.org/10.21776/ub.habitat.2020.031.2.10

\section{Introduction}

The concept of sustainable agriculture development, one of the requirements be able to progress and develop a business is continuous innovation. Innovation can improve the quality and quantity of agricultural products so that in the long run the welfare level of farmers will also increase. But the new technology that has been introduced at the farm level is still not fully adopted by all farmers. One of the reasons is farmers do not play their own role in innovation decision making, considering there are still weaknesses in terms of cognitive, affective and psychomotor. Demand for information and innovation in development is growing in line with the many development programs involve trained staff but not design innovation supported.

*Correspondence Author.

E-mail: rinipurwiyati378@yahoo.com
At the other hand, many research findings are not innovative because there is no adequate dissemination. Information and communication technology (Information and communication technology) are available, but not yet / not optimally used for dissemination of information / innovation. Asymmetric and unequal agribusiness processes existed in the society, which were more favorable for the downstream parties or businesses in the agribusiness system and detrimental to the upstream or the main agricultural actors managing the farming (Sumardjo, 2017). Such information gaps could occur apart from being caused by gaps or lack of information systems which farmers or extension agents or agents for rural or agricultural growth could access. This condition required the development of a Cyber Extension (CE) that could respond to the information needs of actors in the agribusiness system, both upstream and downstream, so that the weakening of the 
information gap of the agribusiness system through CE caused stronger synergy and fairness in the business relationships of upstream, downstream actors as well as the role of institutional support for agribusiness such as financial institutions and extension workers (Sumardjo, 2017).

Agricultural information is one of the most important factors in production and there is no denying that information on agriculture can lead to the development expected. Agricultural information is the best use of knowledge to promote and create opportunities for development and poverty alleviation. Effective incorporation of communications information technology (ICT) into the agricultural sector can contribute to sustainable agriculture through timely and appropriate preparation of agricultural information which can provide farmers with the right information to improve their productivity in the decision-making process. ICTs can rapidly boost the access of farmers to market information, production inputs, consumer trends that have a positive effect on the quality and quantity of their products. Marketing information, new livestock and plant management practices, plant / livestock diseases and pests, transport quality, business demand information, and agricultural input and production market prices are very relevant for economic production efficiency (Maureen, 2009).

Dissemination of information is different from adopting technological innovation. Dissemination of information is the spread of information (only limited to the spread of information and not necessarily that information is received and applied). While the adoption of innovation is the process of receiving information until the information is applied.

The information dissemination process requires media (communication tools) so that the information dissemination process affects the pace of innovation acceptance which ultimately determines the farmer to accept or reject the innovation. This is consistent with Harianta's (2011) viewed that the pace of adoption could be seen from the instructor's activities, especially regarding the instructor's efforts to encourage innovation.

In general, an individual's optimum acceptance of innovation decisions is faster than when an organization makes them. The more people involved in taking decisions, the higher the pace of adoption (Adawiyah, 2017). Means one way of speeding up the implementation of an invention is to seek to pick a decision-making unit with fewer people (individuals). The medium of communication used to spread an innovation might also have an impact on the pace of the innovation acceptance process (Adawiyah, 2017).

The communication channel used was likely to influence the process of adopting technological innovation, so it was important to investigate the degree to which the communication channel influenced in this case the internet-based communication media and the form of media in the adoption process, as well as the degree to which adoption affected an increase in strategic food commodity of Nganjuk Regency.

\section{Research Methodology}

This survey research was an explanatory/confirmatory survey, which was to explain the causal relationship and hypothesis testing (Neuman, 2017).

The research was carried out in Nganjuk Regency, from June to September 2019. The population in this study were farmers and farmer group members in Nganjuk District which consisted of 20 sub-districts, 284 villages and each had a different number of farmers in each village. Based on Simtem Agricultural Counseling Management (SIMLUHTAN 2019) in Nganjuk District there were 1424 farmer groups.

The sample selection method in this study was Simple Random Sampling, which was the process of taking samples by creating a sampling frame and using a pure random process to select several cases so that each sampling element in the population would have the same probability to be selected (Neuman, 2017).

This research was designed using the SEM method approach. According to Ferdinand (2002), that the sample size for testing the model using SEM were: (1) 100 - 200 respondent samples taken or (2) 5 - 10 times the number of parameters estimated, i.e. the number of respondent samples taken was 5-10 times the variable under study. According to Ferdinand (2002), any of these guidelines could be used in research which used SEM analysis tools.

On the basis of both approaches 110 respondents were taken to be safer if in the analysis process there had to be a number of samples removed because the observations were outlier data. 
In this analysis, the data required included primary and secondary data of a quantitative nature. The variables analyzed in this study were (X1) Cyber Extension Media, (X2) Social Media, (Y1) Technological Innovation Adoption.

Operational concepts were definitions and guidelines concerning the variables used in this study for obtaining data to be analyzed and evaluated in accordance with the research objectives. Operational Definitions were descriptions based on the characteristics of specified objects which could be observed (Umar, 2004). So that there were similarities in terms of opinions, between the perspective of researchers and readers in seeing the results of research, the affirmation of some terms or limits of understanding of some terms that were considered necessary.

The study was designed using the SEM (Structural Equation Model) approach with the help of AMOS 21 application. SEM was a multivariate analysis technique that enabled researchers to examine the relationship between complex variables both recursive and nonrecursive in order to obtain a detailed picture of the model (Ghozali, 2005). The SEM model was chosen because there was an interaction between the agricultural extension media of the Cyber extension with the innovation adoption and the communication media with the innovation adoption. Understanding the effect of the Cyber extension media and communication media on the innovation adoption using a regression equation in SEM.

Furthermore Sugiyono (2004) argued that there was a gradation from very positive to very negative in the response for each instrument using a Likert scale. Likert scale model consisted of points that displayed strongly agree (SS), agree (S), Fair (C), disagree (TS) and strongly disagree (STS). The study variables were described with the respondents' answer in order to provide a description of the appropriate conditions. In the description analysis there were variations in the form of a table containing the average of the question items (Solimun, et.al. 2017).

In the questionnaire, the answers provided by the respondents used the measurement of class intervals or interval width as parameters for evaluating the average score. The highest score was 5 and the lowest score was 1 , so the range $R$ $=5-1=4$ was obtained, then the width $\mathrm{k}=4 / 5=$ 0.8 was obtained.
The interpretation of each respondent's answer as follows:

$$
\begin{aligned}
1,00-1,8 & =\text { very low } \\
1,8>-2,6 & =\text { low } / \text { poor } \\
2,6>-3,4 & =\text { moderate } \\
3,4>-4,2 & =\text { high } / \text { good } \\
4,2> & =\text { very high / very good }
\end{aligned}
$$

\section{Results and Discussions}

\subsection{The Characteristics of Respondents by Age}

The profile of the respondent explained the identity of the respondent, which included gender, age, education and land area control. These characteristics were taken into account because they had an impact on the process of innovation diffusion at the stage of innovation adoption. Characteristics of respondents by age could be found in Table 1 below:

Table 1. The Characteristics of Respondents by Age

\begin{tabular}{lrc}
\hline \multicolumn{1}{c}{ Information } & Frequency & Percentage \\
\hline$<30$ years old & 1 & 0,9 \\
$30-40$ years old & 27 & 24,5 \\
$41-50$ years old & 55 & 50,0 \\
$>50$ years old & 27 & 24,5 \\
\hline Total & 110 & 100 \\
\hline
\end{tabular}

Based on the data presented in Table 1, it was known that the age range of respondents in this study was dominated by 50.0 per cent between 41 and 50 years of age. The highest percentage of respondents between 41 and 50 years of age showed that the age of farmers at the time of the study was at the productive age of farming management.

\subsection{The Characteristics of Respondents by Gender}

Based on the gender, it was known from the data provided in Table 2 that $86.4 \%$ of the respondents in this study were male and only $13.6 \%$ were female. It indicated that women also played an active role in the management of farms in Nganjuk Regency.

Table 2. The Characteristics of Respondents by Gender

\begin{tabular}{lrr}
\hline Information & Frequency & Percentage \\
\hline Male & 95 & 86,4 \\
Female & 15 & 13,6 \\
\hline Total & 110 & 100 \\
\hline
\end{tabular}


Farmers or respondents of this study were in farmer organizations or institutions or called groups of farmers or farmer groups. There were 3 groups of farmers (poktan) namely adult farmers (whose members were adult male farmers), Women Farmers Group (KWT), namely farmers with members of farmer mothers (the main perpetrators were women), and Taruna Tani, farmers groups whose members were members young farmers. The institutional condition of farmers in Nganjuk Regency was the group of adult farmers (based on the age group and gender of their members).

This showed that the majority of farmer institutions in Nganjuk Regency were still dominated by adult (male) farmer groups, however the presence of female respondents indicated the role and involvement of women in farmer group activities, given the respondents in this study were group leaders or administrators active in groups of farmers. At the moment in Nganjuk Regency, growing groups of women farmers had both on-farm and off-farm activities and had active activities.

\subsection{The Characteristics of Respondents by Educational Level}

On the most recent educational side, it was known from the data provided in Table 3 that the respondents to this study were 54.5 per cent from high school level. This indicated that the level of education of farmers in the group was very high. In general, Nganjuk Regency farmers who were able to access information through Information Technology (IT), in this case Internet Information Technology, were high school farmers up to undergraduate level. According to Mulyandari (2011) farmers appeared to have fairly high education in accessing information technology because information technology was a modern type of communication that required relatively high knowledge compared to other communication media.

Table 3. The Characteristics of Respondents by Educational Level

\begin{tabular}{lrr}
\hline Information & Frequency & Percentage \\
\hline Elementary & 4 & 3,6 \\
Junior High & 17 & 15,5 \\
School & 60 & 54,5 \\
High School & 10 & 9,1 \\
Diploma & 18 & 16,4 \\
Undergraduate & 1 & 0,9 \\
Postgraduate & 110 & 100 \\
\hline Total &
\end{tabular}

The educational level also influenced attitude, namely the tendency to act due to external stimuli. This tendency to act would be influenced by someone's knowledge. Someone's knowledge could be seen from the level of education. The more extensive someone's knowledge, his attitude would tend to be good.

\subsection{The Characteristics of Respondents by Land Tenure}

Based on the level of land tenure listed in table 4, it was known that 48 percent of farmers owned $0.5-1 \mathrm{Ha}$ of land. This illustrated that land with such an area was still categorized narrow by farmers in farming. This was experienced by farmers, especially when developing the cultivated commodity that was very limited due to the restricted area of land owned.

Table 4. The Characteristics of Respondents by Land Tenure

\begin{tabular}{|c|c|c|}
\hline Information & Frequency & Percentage \\
\hline$<0,5 \mathrm{Ha}$ & 42 & 38,2 \\
\hline $0,5-1 \mathrm{Ha}$ & 53 & 48,2 \\
\hline $1,1-2 \mathrm{Ha}$ & 9 & 8,2 \\
\hline$>2 \mathrm{Ha}$ & 6 & 5,5 \\
\hline Total & 110 & 100 \\
\hline
\end{tabular}

Sasongko, et.al. (2014) argued that the more extensive land owned by farmers, the need for information technology would be higher in order to achieve the efficiency and effectiveness of the resources used. This made farmers actively involved in the search for information and in the transmission of information to farmers and other interested parties. The more land owned, the attitude of farmers would be more positive because of the tendency to carry out farming activities that were more effective and efficient. Also supported by Lionberger in Mardikanto (2009), the wider the farming business was, the faster it would adopt innovation, because it had better economic capacity.

Based on the respondents' description, it could be concluded that during the study the respondents were dominated by respondents in the age range $41-50$ years, male sex, senior high school education, and owned 0.5 - $1 \mathrm{Ha}$ area.

\subsection{The Perception of Farmers Regarding Cyber Extension Socialization Media}

Cyber extension was one of the information systems that could be used as a driver for the management of dissemination, 
documentation, retrieval, sigerisasi technological innovations needed by farmers to support the development of sustainable agricultural innovations. The development of information and communication technology, especially the emergence of mobile phones and the Internet, had led to major changes in community life in Nganjuk Regency. According to Leewis (2009), the diversity of communication media was more combined with new packages, so the boundaries between media categories became more blurred, internet-based communication media was more widely used to interact with the audience than other communication tools. So that the process of innovation diffusion occured wider and faster.

To find out about the use of cyber extensions and communication media in social media such as Facebook, WhatsApp and Youtube. The Cyber Extension variable was measured using three indicators, namely the openness to communication media, the farmer interaction with the use of Cyber Extension, and the perception of farmers in Cyber Extension.

Table 5. The Mean Variable of Cyber Extension Socialization Media

\begin{tabular}{lc}
\hline \multicolumn{1}{c}{ Indicator } & Mean \\
\hline $\begin{array}{l}\text { The openess to commucation } \\
\text { media }\end{array}$ & 4,18 \\
$\begin{array}{l}\text { The farmer interaction with } \\
\text { the use of Cyber Extension }\end{array}$ & 3,81 \\
$\begin{array}{l}\text { The perception of farmers in } \\
\text { Cyber Extension. }\end{array}$ & 3,64 \\
\hline Average & 3,88 \\
\hline
\end{tabular}

In Table 5, obtained the average value of respondents' perceptions for all questions related to the dimensions of the openness to communication media, the farmer interaction in the use of Cyber extensions, and the farmer interaction in the use of Cyber extensions tended to be high. Out of the three indicators, openness to communication media had the highest average value of 4.18. When viewed as a whole in table 5, all indicators were in the high category with a mean score of 3.88. It defined that out of the three indicators, the openess was the most influential factor on the use of Cyber extensions as agricultural extension media in obtaining new technology information.

The openness to communication media could be seen from the types of communication tools chosen and used, the length of time to recognize and use communication tools, facilities supported the use of communication tools and the amount of desire to use communication tools in searching for information. According to Yusuf (2009) in the theory of Uses and Gratification, the meeting between a person's needs with information obtained from the media encouraged someone to be more active in choosing and using certain media to meet certain needs. To achieve effective communication, the media must be well considered (Lionerberger and Gwin, 1992). The behavior of farmers in choosing and using ICTbased information sources in rural areas was very necessary because the village had the right to enjoy easy access to information through information and communication technology.

Based on the results of the analysis that farmers' perceptions of the Cyber extension socialization media were potential Cyber extensions as an effective agricultural extension media, then internet-based information fulfillment through Cyber extensions. Therefore, it was necessary to strengthen the aspects of Cyber extension by: (a) increasing ownership of information technology, (b) increasing accuracy, completeness, sharpness and accuracy of information by involving more stakeholders, (c) forming an internet user group container can increase farmers 'knowledge about cyber extensions and (d) conduct training, mentoring to improve farmers' skills using ICT, Gultom et al. (2017).

\subsection{The Perception of Farmers Regarding Communication Media Facebook, Whatsapp, and Youtube}

The following was a mean table of communication media variables consisting of indicators of the communication media types in this case were social media that had been widely used by the public, namely Facebook, WhatsApp and Youtube.

Table 6. The Mean Variable of Communication Media

\begin{tabular}{lc}
\hline \multicolumn{1}{c}{ Indicator } & Mean \\
\hline Facebook & 3,67 \\
WhatsApp & 3,97 \\
Youtube & 3,86 \\
\hline Average & 3,83 \\
\hline
\end{tabular}

The table 6 above displayed the average acquisition of indicators for building communication media variables. The three indicators had a high average score and the average communication media WhatsApp (WA) ranked highest at 3.97, and overall score 
indicators were high in the average category with a mean value of 3.83. To measure WA indicators, sub indicators were used which included the length of time using WA, reasons for using social media: WA was a social media that suited your needs, easy to use and reached broad communication. Some reasons people used the WA application included: (1) easy to use and simple, (2) available on a variety of devices, (3) inexpensive, (4) did not know the borders of the country. The used of social media, namely through the WA social network, might increase knowledge and exchange information on agricultural technology. Useful social media added knowledge and functions as a communication tool if; (1) providing information, (2) providing feedback, (3) influencing solving the problem at hand.

The impact of the use of social media, namely the impact of using WA as a medium of communication, information and knowledge affected on farming habits and methods.

Communication media indicators in the form of social media for instance Facebook, WhatsApp and Youtube were interpersonal media types and selected by farmers as a source of information. In the research results, Suryantini (2004) mentioned four main reasons respondents used information sources, namely: (1) the desire to simply know or add experience, (2) the desire to obtain up-to-date information, (3) the desire to obtain knowledge that was in accordance with needs or to solving the problem at hand and (4) the desire to develop oneself to be better.

\subsection{The Perception of Respondents Regarding Innovation Adoption}

Table 7 below showed three indicators that built innovation adoption variables, namely the credibility / level of media trust, attitude, and motivation. Out of the three indicators, the most powerful and dominant in influencing the innovation adoption was motivation indicator with a mean value of 4.2. The average for the three indicators in the high category was 4.03.

Table 7. The Mean Variable of Innovation Adoption

\begin{tabular}{lc}
\hline \multicolumn{1}{c}{ Indicator } & Mean \\
\hline The credibility/level of media trust & 3,8 \\
Attitudes & 4,1 \\
Motivation & 4,2 \\
\hline Average & 4,03 \\
\hline
\end{tabular}

This illustrated that the use of information technology based on Cyber extension and the use of communication media in the form of social media were effective in providing information technology that could be accessed by farmers in Nganjuk Regency in developing their farming business. This was also in line with the results of Amin's research (2014). Motivation was one of the factors that influenced the innovation adoption, it stated in the results of Kusumaningrum (2012) research on the factors that influenced the application of rice cultivation found that motivation had a significant effect on the application of modern rice cultivation. It meant that the greater the motivation of farmers, the higher the application of technological innovation. Sasongko and Harsono (2014) suggested that farmers who had high motivation in utilizing information technology tended to be positive towards innovation. This was certainly related to efforts in fulfilling the needs of his life, the need for better and more prosperous through his farming.

\subsection{The Influence of Cyber Extension Socialization Media and Communication Media on Innovation Adoption}

Cyber extension was an online extension media developed by the Agricultural Human Resources and Development Agency which intended to make information services easier, faster, accurate, appropriate with farmers' needs, and easily accessed by farmers. The needs for information were accelerating and increasing among farmers following the development of technology and motivation to manage farming in better way. The development of information at this time, particularly based on the internet was widely available through various communication channels, so that the extension media and communication media become very important in the process of delivering agricultural technology information until the information becomes a recommendation that is accepted and implemented through the process of innovation adoption. The production of information at this period, particularly on the Internet, became widely available via various communication networks, so that the extension and communication media were very significant in the process of providing information on agricultural technology before the information became a recommendation that accepted and implemented through the innovation adoption 
process. In Nganjuk Regency, the Cyber extension media had been introduced since 2013 to farmers and had undergone many changes and developments for the better. So, it was necessary to do a measurement to what extend the influence of extension and educational media on the innovation adoption by farmers in Nganjuk Regency. Based on the causality test, Cyber Extension had a positive influence on the innovation adoption by 0.438 and also influenced by communication media at 0.482 with a significant level of 5\%.

The innovation adoption in agriculture was the result of an agricultural community's activities and the community arena that involved social interaction among people, so the process of innovation adoption was related to the interaction between individuals, groups, members of society or community groups, also influenced by interactions between groups in society (Sukarwati, 2005). Channels or communication media was required in the stages of adoption process. The facilities or media included cyber extension and communication channels or media. Mulyandari (2010) stated that the cyber extension system supported the entire process of farm development including production, management, marketing and other rural activities. The existence of cyber extension could support the function and role of extension agents in providing and accelerating the flow of information dissemination by utilizing an internet network that bridged the main actors (farmers) with research institutions and entrepreneurs. The success of an agricultural technology innovation was determined by how much the technology was adopted and used by farmers. One way to accelerate the innovation adoption was attempting to choose a decision-making unit, and the channels or communication media used to spread innovation also influence the innovation adoption.

The information and communication technology were developing so rapidly. This progress had an extraordinary influence in various fields of human life. Whether we realized it or not, information and communication technology had helped to launch human activities in various fields. The search for information needs through the participation in the communication process mechanism was carried out by humans as an effort to further improve, repair, and update their standard of living as the progress of human civilization.

Cyber extension as agricultural socialization media had a positive and significant effect on the innovation adoption. This was because the estimated value shown was positive, which was equal to 0.438 with a C.R of 3.806 . Where was the value of C.R. greater than 1.96 and $\mathrm{p}$-value $<0.05$. A positive estimate value indicated that the better Cyber extension as agricultural extension media, the more likely it was to be able to increase Innovation Adoption.

According to Prayoga (2018), the Cyber extension was present in providing a positive influence on human life. While according to Bourdeun, the Cyber extension as an arena that contained capital battles needed by farmers who had extension agents, created new habitus, and connected different social prior to the discussion activities carried out in a virtual room, the core of both was the changing mechanism as the process of adopting innovation.

Media Komunikasi berpengaruh positif dan signifikan terhadap Adopsi Inovasi. Hal ini dikarenakan nilai estimate yang ditunjukkan bernilai positif, yakni sebesar 0.482 dengan C.R sebesar 3,518. Dimana nilai C.R. lebih besar dari 1,96 dan nilai $p$-Value $<0,05$. Nilai estimate yang bernilai positif menunjukkan bahwa semakin baik Media Komunikasi maka cenderung dapat meningkatkan Adopsi Inovasi.

Communication media has a positive and significant effect on the innovation adoption. This was because the estimated value considered was positive, which was 0.482 with a C.R of 3.518. The value of C.R. greater was than 1.96 and $\mathrm{p}$-value $<0.05$. The positive estimated value indicated that the Communication Media was needed to improve the Innovation Adoption.

Table 8. The Results of Estimation and Significance of Variables Influence

\begin{tabular}{|l|c|c|c|c|}
\hline \multicolumn{1}{|c|}{ Relation } & Estimation & C.R & P & Information \\
\hline Agriculture Socialization Media Cyber extension $\rightarrow$ Innovation Adoption & 0,438 & 3,806 & 0,000 & Significant \\
\hline Communication Media $\rightarrow$ Innovation Adoption & 0,482 & 3,518 & 0,000 & Significant \\
\hline
\end{tabular}

Based on table 8 , the magnitude of the coefficients of each factor was more reliable as seen in the causality test as follows: Model Y1 =
$0.438 \mathrm{X} 1+0.482$ X2Sadono (2009), conveyed the influence of social media on the adoption of technological innovations by farmers that the 
influence of the mass media channel especially by farmers in developing countries would be greater if the mass media was combined with interpersonal communication channels. Media forums were considered the most effective way at that time to reach the wider community with innovation then influenced them to use innovation. Harinta (2011) in her study concluded that communication channels, the nature of innovation and prospective users' characteristics had a positive effect on the speed of innovation adoption, and indicators of communication channels that affected the speed of adoption were interpersonal and mass media channels.

\section{Conclusions}

a. Openness to the media has the highest score on the Cyber Extension extension variable due to the ownership of communication tools, the choice of communication tools, the availability of communication networks and the high desire to find suitable information is a need for farmers to improve their farming.

b. WhatsApp communication media indicator has the highest score on the communication media variable due to the communication media according to the needs of farmers in Nganjuk Regency, the easiness to use and able to reach broad communication.

c. Motivation has the highest score on the innovation adoption variable due to the existence of individuals in the communication process to add insight and meet their needs to grow and develop better.

d. Cyber extension socialization media and communication media influence the innovation adoption, because appropriate extension media and communication media can accelerate the process of innovation adoption.

e. Openness to the media, types of communication media and motivation influence the use of Cyber extension as socialization and communication media towards the innovation adoption.

The process of technological adoption innovation by farmers is individual or group and influence by the media and communication channels chosen and used, so that it is necessary to optimize the use of internet-based communication media to reach the main actors (farmers) both individually and in groups to accelerate the adoption of agricultural technology innovation.

\section{References}

Adawiyah C.R., 2017. Urgensi Komunikasi Dalam Kelompok Kecil Untuk Mempercepat Proses Adopsi Teknologi Pertanian, Forum Penelitian Agronomi Vol. 35 No. 1 Juli 2017 : 5974.DoI:http//dx.doi.org/10.21082/Fae.V35 nI.2017.59-74.

Amin. Muh., 2014, Efektivitas dan Perilaku Petani Dalam Memanfaatkan Teknologi Informasi. Balai Pengkajian Teknologi Pertanian Sulawesi Tengah.

Ferdinand. 2002. Metode Penelitian Manajemen: Pedoman penelitian untuk Skripsi, Tesis, dan Desertasi Ilmu Manajemen, Semarang : Badan Penerbit Universitas Diponegoro.

Gultom, D.T., et.al., 2017. Strategi Pemenuhan Kebutuhan Informasi Pertanian Melalui Pemanfaatan Cyber extension di Provinsi Lampung.Sosiohumaniora Vol. 19 No. 1 Maret 2017 : 64-69.

Harianta Y.W., et al., 2011. Adopsi Inovasi Pertanian di Kalangan Petani Kecamatan Gatak Kabupaten Sukoharjo, Agrin Vol. 15, No. 2 Oktober 2011. ISSN: 1410-0029.

Kusumaningrum, A., 2012. Faktor-Fakror yang Mempengaruhi Penerapan Budidaya Tanaman Padi Secara Modern dan Tradisional di Kecamatan Bayan Kabupaten Purworejo. Fakultas Pertanian.Universitas Gadjah Mada.

Lionerberger H.F. dan Gwin. 1992. Technology Transfer. Illinois: The Interstate Orienters and Publiesh, Inc.

Maureen. 2009. How Can ICTs Promote Sustainable Agricultural (terhubung http://www.citizenjournalismafrica.org/blo g/\%5Buser\%5D/05-aug-2009/1856(12 Desember 2009)

Mulyandari et al., 2010, Implementasi Cyber extension Dalam komunikasi Inovasi Pertanian, Informasi Pertanian Vol. 19 no 2, 2010. 
Mulyandari, R.S.H. 2011. Perilaku Petani Sayuran dalam Memanfaatkan Teknologi Informasi. Jurnal Perpustakaan Pertanian 20(1): 22-34.

Neuman, W.L., 2017. Metodologi Penelitian Sosial Pendekatan Kualitatif dan Kuantitatif. PT. Indeks, Jakarta.

Prayoga K., 2018. Dampak Penetrasi Teknologi Informasi Dalam Transformasi Sistem Penyuluhan Pertanian di Indonesia, JESP Vol. 11 No. 1 Maret 2018.

Sadono, D., 2009. Perkembangan Pola Komunikasi Dalam Penyuluhan Pertanian di Indonesia. Jurnal Komunikasi Pembangunan Juli 2009. Vol.07. no. 2.

Sasongko, W.A. et.al., 2014. Pengaruh Perilaku Komunikasi Terhadap Sikap dan Adopsi Teknologi Budidaya Bawang merah di Lahan Pasir Pantai.

Solimun, A.A.R. Fernandes \& Nurjanah. 2017. Pemodelan Persamaan Struktural (SEM) Pendekatan WARPPLS.UB Press. Malang.

Sugiyono, 2004. Statistika untuk Penelitian. Penerbit CV. Alfabeta. Bandung.

Sumardjo, 2017, Cyber extension: Peluang dan Tantangannya dalam revitalisasi Penyuluhan Pertanian.

Suryantini et al., 2004, Pemanfaatan Informasi Teknologi Pertanian Oleh Penyuluh Pertanian : Kasus di Kabupaten Bogor. Jawa barat. Jurnal Perpustakaan Pertanian Vo. 13. Nomor 1, 2004.

Umar, H. 2004. Riset Pemasaran dan Perilaku Konsumen. PT. Gramedia Pustaka Utama. Jakarta.

Yusuf, P., 2009. Ilmu Informasi, Komunikasi dan Kepustakaan. Jakarta. PT. Bumi Perkasa. (ind). 